UDC 341.1

DOI https://doi.org/10.32782/2524-0374/2020-2/115

\title{
PROBLEMS OF JUDGMENTS EXECUTION OF THE EUROPEAN COURT OF HUMAN RIGHTS IN UKRAINE
}

\author{
ПРОБЛЕМИ ВИКОНАННЯ РІШЕНЬ \\ ЄВРОПЕЙСЬКОГО СУДУ 3 ПРАВ ЛЮДИНИ В УКРАЇНІ
}

\author{
Horchakova V.S., Student of the Master's Degree \\ of the Faculty of Economics and Law \\ Yaroslav Mudryi National Law University \\ Yaroshshuk A.S., Student of the Master's Degree \\ of the Faculty of Advocacy \\ Yaroslav Mudryi National Law University
}

\begin{abstract}
The article explores the judgments implementation of the European Court of Human Rights (hereinafter referred to as the ECHR).
The procedure, its peculiarities and stages of implementation of ECHR judgments in accordance with national legislation, depending on the type of obligations of the state, established by ECHR judgment are covered. The procedures of payment of compensation (just satisfaction), implementation of measures of individual and general character are investigated.

The purpose of the article is to identify and analyze problems that arise during the implementation of due process and procedural actions and make it impossible to reverse the ECHR judgment for the benefit of the citizen of Ukraine for enforcement. The study paid much attention to the causes of non-compliance with just satisfaction, namely: estimates in the budgets of Ukraine of funds that are much less than the number of payments to be made in proceedings opened by the ECHR; the inability of financial support by the state of positive obligations in the field of social protection of citizens. It also emphasizes the importance of implementing measures of a general nature by which the State undertakes to remedy problems in the internal law and order.

In addition, attention is paid to possible ways of solving the relevant problems, which require, first and foremost, the legislative will, which may include legislative measures to increase appropriations for the relevant state budget expenditures, the establishment of a Fund for Guaranteeing Compensation under the Judgment of the ECHR, balancing financial opportunities and obligations which the State undertakes, publication and dissemination to national courts of ECHR judgments in order to avoid further violations of the Convention, educational work, etc.

The conclusion emphasizes the need to take organizational and legal measures to improve the national procedure for implementing ECHR judgments, which will not only improve Ukraine's fulfillment of its obligations under the Convention for the Protection of Human Rights and Fundamental Freedoms, but also promote integration into the European space.

Key words: Convention for the Protection of Human Rights and Fundamental Freedoms, European Court of Human Rights, execution of judgments.
\end{abstract}

У статті досліджується питання виконання рішень Європейського суду з прав людини (далі - ЄСПЛ).

Висвітлено процедуру, її особливості й етапи виконання рішень ЄСПЛ згідно з національним законодавством залежно від виду зобов'язань держави, встановлених рішенням ЄСПЛ. Досліджено порядок виплати відшкодування (справедливої сатисфакції), виконання заходів індивідуального та загального характеру.

Завдання статті полягає у виявленні й аналізі проблем, які виникають під час реалізації належних процесуальних і процедурних дій та унеможливлюють виконання рішення ЄСПЛ на користь громадянина України. У дослідженні значну увагу приділено причинам невиконання справедливої сатисфакції, а саме: передбачення у бюджетах України коштів, значно менших, аніж суми виплат, що повинні бути проведені за провадженнями, відкритими за рішеннями ЄСПЛ; неможливість фінансового забезпечення державою позитивних зобов'язань у сфері соціального захисту громадян. Також звертається увага на важливість забезпечення виконання заходів загального характеру, за допомогою яких держава зобов'язується усунути проблеми у внутрішньому правопорядку, шляхи та засоби яких обирає сама держава.

Крім того, пропонуються можливі шляхи вирішення відповідних проблем, які потребують передусім законодавчої волі, зокрема здійснення законодавчих заходів щодо збільшення асигнувань на відповідні видатки державного бюджету, створення Фонду гарантування виплати відшкодувань за рішенням ЄСПЛ, урівноваження фінансових можливостей і зобов'язань, які держава бере на себе, опублікування й поширення серед національних судів рішень ЄСПЛ з метою уникнення надалі можливих порушень Конвенції, просвітницька робота тощо.

У висновку наголошується на необхідності здійснити організаційні та правові заходи для удосконалення національної процедури виконання рішень ЄСПЛ, що не тільки покращить виконання Україною своїх зобов'язань за Конвенцією про захист прав людини й основоположних свобод, а й сприятиме інтеграції у європейський простір.

Ключові слова: Конвенція про захист прав людини та основоположних свобод, Європейський суд з прав людини, виконання рішень.

The relevance of topic. Resolutions of the Parliamentary Assembly of the Council of Europe constantly draw attention to systemic problems with the execution of the European Court of Human Rights judgments related to the payment of damages and the taking of individual and general measures. The Committee of Ministers of the Council of Europe views the problem of non-execution of judgments as a fundamental dysfunction of the judicial system, which violates the right of persons to access to court, violates the rule of law and destroys confidence in the functioning of the judicial system and justice in general.

Despite its well-designed decision-making process, Ukraine is still among the countries that do not comply with its obligation. According to the European Enforcement Network (EIN), which represented an interactive map with information on 47 countries in Europe, over the last 10 years, Ukraine has not complied with $67 \%$ of the leading judgments of the European Court of Human Rights against Ukraine. The rate of implementation of such judgments by Ukraine is one of the worst in Europe, higher only in Hungary (74\%) and in Russia (89\%) [1].

The degree of scientific development. Various aspects of the implementation of judgments of the European Court of Human Rights in Ukraine are researched in scientific works of such scientists as N.V. Kaminski, A.Yu. Kapitonenko, U.Z. Koruts, S.Yu. Marochkina, P.V. Pushkar, N.V. Schelever, D.M. Suprun, S.R. Tagieva, and others.

The purpose of the article. The purpose of the article is to explore the features and procedures of the implementation of judgments of the European Court of Human Rights in Ukraine, as well as the problems that arise in their implementation.

The main body. Aspecific feature of the conventional human rights protection mechanism is that, despite the declaratory nature of human rights in the text of the Convention, cases of violations by States of their obligations not only serve as 
a basis for their responsibility, but there are guarantees for the restoration of the violated rights of individuals and legal entities, and creation of national preventive measures to prevent such violations from happening again in the future [2, p. 46]. Execution of judgments of the European Court of Human Rights in Ukraine is governed by the Convention for the Protection of Human Rights and Fundamental Freedoms, the Laws of Ukraine: "On the Execution of Judgments and the Practice of the European Court of Human Rights", "On Executive Proceedings", "On Guarantees of the State to Execute Judgments".

According to Art. 46 of the Convention for the Protection of Human Rights and Fundamental Freedoms, The High Contracting Parties undertake to abide by the final judgment of the Court in any case to which they are parties. The final judgment of the Court shall be transmitted to the Committee of Ministers, which shall supervise its execution [3].

As for the national mechanism, the coordination of the implementation of these judgments is carried out by the Ministry of Justice through the Ombudsman of the European Court of Human Rights. The relevant procedure is provided for by the aforementioned Law of Ukraine "On the Execution of Judgments and the Practice of the European Court of Human Rights" and is as follows:

1. Within ten days from the date of receipt of the notice of the Court on the status of the final decision the Ministry of Justice of Ukraine

- prepares and sends a summary of the Judgment in Ukrainian for publication in the "Uryadovyi kurier" newspaper;

sends a concise statement of the Judgment to the Claimant, the Ombudsman of Ukraine, to all public authorities, officials and other entities directly involved in the case in which the judgments was issued;

- also, it sends a notice to the Claimant explaining his right to apply to the State Bailiffs for compensation, which must include the details of the bank account for the transfer of funds However, it should be noted that the failure of the Claimant to submit a claim for payment of compensation is not an obstacle to the execution of the Judgment;

sends to the State Executive Service the original text and translation of the resolution part of the final judgment of the Court in the case of Ukraine which establishes the violation of the Convention, the original text and translation of the resolution part of the final judgments of the Court on just satisfaction in the case against Ukraine, the original text and translation of the Judgment on the friendly settlement in the case against Ukraine, original text and translation of the Court's judjment approving the terms of the unilateral declaration in the case against Ukraine.

2. The State Executive Service within ten days from the date of the receiving of documents opens the executive proceedings.

Thus, as general rule, it is the Ministry of Justice of Ukraine is the initiator of the enforcement proceedings and not the Claimant.

The further procedure depends on the type of state obligations imposed by the ECHR judgment. These can be:

1) Payment of compensation (just satisfaction) payable within three months from the date of the judgment becoming final or within the period determined in the Judgement. If such a term is violated, the Law provides for the payment of a fine. To pay fair compensation, the Ministry of Justice within a month sends to the State Treasury Service a decree to open executive proceedings, and within the last 10 days, debits funds to the bank account specified by the Claimant, and in the absence of such funds, to the deposit account of the state bailiffs according to the relevant budget program of the State Budget of Ukraine.

It should be noted that, since 2011, the procedure for monitoring the payment of just satisfaction has been simplified. And now there is the responsibility of the applicant, who should inform the Committee of Ministers of the Council of Europe within two months if the State has submitted information on the payment of compensation but it was not received. If no complaint is received, the payment issue will be considered closed.

And with the confirmation of the State Treasury Service of Ukraine of transfer of funds, the executive proceedings end.

2) Implementation of measures of individual character, such as:

a) restoration, as far as possible, of the previous legal status of the Claimant prior one before the violation of the Convention (restitutio in integrum);

b) other measures provided for in the Judgement.

The restoration of the previous legal status of the Claimant may be either by a revision of the case by a court (revision in exceptional circumstances) or by a revision of the case by an administrative body. The Ministry of Justice of Ukraine shall notify the Claimant and the authorities responsible for the implementation of these measures within 10 days.

3) Implementation of measures of general character, such as:

- to amend the current legislation and its practice application

- making changes to administrative practice;

- providing legal expertise of bills;

- providing training in the study of the Convention and the practice of the Court for prosecutors, advocates, law enforcement bodies, immigration officials, other categories of law enforcement professionals;

- others.

To implement the relevant measures, the Ministry of Justice of Ukraine quarterly prepares and sends to the Cabinet of Ministers of Ukraine a submission, which includes proposals for solving the systemic problem identified in the Judgement and elimination of its root cause, analytical review for the Supreme Court and proposals to the Verkhovna Rada of Ukraine for drafting in the draft law [4].

One of the reasons for not fulfilling the just satisfaction is that the budgets of Ukraine contain funds that are much less than the number of payments that should be made in proceedings opened by the ECHR. The budget program "Payments for the Execution of Judgments of Foreign Jurisdictional Bodies Adopted by the Consequences of Litigation Against Ukraine", which is approved by the order of the Ministry of Justice of Ukraine, foresees, following the sums of expenditures per budget year, the number of budgetary appropriations for the implementation of measures related to the execution of the judgments of the European Court of Justice human rights and foreign jurisdictions taken in the aftermath of cases against Ukraine. Thus, for 2020 the amount of budgetary appropriations according to the passport of the mentioned program is UAH 382377,4 thousand, out of which UAH 311 184,3 thousand to recover sums of money by court judgments. Drawing on past data, the amounts assigned to the payments are much higher than those foreseen in the expenditures.

It is worth noting that one of the reasons for not implementing the judgments against the authorities is positive obligations in the field of social protection of citizens, which the state cannot provide financially. It is often the case that the legislature, in the pursuit of popular favor, makes decisions about raising social standards that have not been adopted by the state for implementation. Therefore, when individuals receive court judgments in their favor, the lack of funds in the budget makes it impossible to pay. We consider it is necessary to balance the financial opportunities and obligations that the state incurs.

Attention should be paid to the need for legislative measures to increase appropriations for relevant state budget expenditures. It is fair to note N.V. Schelever's opinion on the feasibility of establishing a Fund for Guaranteeing Payment of Compensation under the judgment of the ECHR, 
which at the expense of the State Budget of Ukraine would ensure $100 \%$ repayment of the State's debts under the relevant executive documents [5, p. 110].

The Law of Ukraine "On State Guarantees for the Enforcement of Judgments" 2012 aims to enforce court judgments. It provides that the judgment on recovery of funds, where the debtor is a public authority, must be executed by the central executive body implementing public policy in the field of treasury servicing of budgetary funds, within the limits of budgetary appointments by debiting funds from the accounts of this state body, and in the absence of the designated state appointing authority - at the expense of the funds provided under the budget program to ensure the enforcement of court judgments. If the court's judgment to recover funds from a state-owned enterprise or legal entity is not executed within six months from the date of the judgment to open enforcement proceedings, its execution shall be carried out at the expense of the funds provided for in the budget program to enforce court judgments. If the funds are not transferred within three months, the collector is compensated at the rate of three percent per annum from the unpaid amount at the expense of the funds provided for in the budget program for the enforcement of court judgments [6].

To ensure that similar human rights abuses are not committed, ECHR judgments provide for general measures. Thus, the state itself chooses the measures by which it undertakes to eliminate problems in the internal law and order. For example, if the result of a violation of rights hides problems with specific laws or lack of proper legislation, then it will be appropriate to amend the regulations or adopt the relevant laws. However, as practice shows, for instance, the failure of Ukraine to comply with a significant period of the pilot judgment "Yury Ivanov v. Ukraine" of 15.10.2009 (failure to enforce court judgments against public authorities) may indicate an inability or unwillingness to find the resources to carry out the necessary legal or legislative reforms.

It is important to note that at present the use of ECHR practice in national court judgments is rather confusing; in many cases judges refer to specific judgments, but without specifying how they relate to the circumstances of the case and their relation to the rules of national law. However, D.M. Suprun argues that the publication and announcement of ECHR judgments to national courts could be a sufficient preventive measure of a general nature to avoid further violations of the Convention. It is this effect of the judgments of the jurisdictional control mechanism of the Convention that distinguishes it from other control mechanisms in the system of modern international law [7, 851p.]. Therefore, attention should be paid to the educational work towards identifying the place for judgments of ECHR as a source of law and the obligation to apply court practice.

Conclusions. Due to Ukraine's desire to move closer to the European space, it is necessary to pay attention to the reasons for Ukraine's failure to comply with the ECHR's judgments and to take measures to overcome them, since such inaction demonstrates the weakness of the state, including the inability to ensure a proper level of law and order. The aforementioned problems testify to the urgent need to create all possible organizational and legal conditions for the timely implementation of ECHR judgments, which in turn would facilitate Ukraine's development in the context of integration with the European community.

\section{REFERENCES}

1. ECHR Enforcement Report of the European Network of Enforcement Solutions (EIN). URL: http://www.einnetwork.org/countriesoverview.

2. Theory and Practice of Application of the Convention for the Protection of Human Rights and Fundamental Freedoms : Compendium / by General. editors: O.V. Serdyuk, I.V. Yakovyuk; Nat. lawyer. them. Yaroslav the Wise, Dept. international. right. Kharkiv : Right, 2017.374 p.

3. Convention for the Protection of Human Rights and Fundamental Freedoms / Convention, International Document 04.11.1950. URL: https://zakon.rada.gov.ua/laws/show/995_004\#n42.

4. Law of Ukraine "On Enforcement of Judgments and Application of the Practice of the European Court of Human Rights" of 23.02.2006 № 3477-IV. Bulletin of the Verkhovna Rada of Ukraine. 2006. № 30. Art.

5. Schelever N.V. Problematic issues of the implementation of judgments of the European Court of Human Rights in Ukraine. URL: http://intlawalmanac.net/v7/13.pdf

6. On State Guarantees of Enforcement of Judgments : Law of Ukraine of 5 June. 2012 № 4901-VI. Bulletin of the Verkhovna Rada of Ukraine. 2012. № 17. Art. 158.

7. Suprun D. Main aspects of Ukraine's entry into the jurisdictional mechanism of the European Convention on Human Rights. European Convention on Human Rights: Basic Provisions, Practice, Ukrainian Context / ed. A. Zhukovsky. Kyiv : VIPOL, 2004. P. 849-855. 